\title{
EUROPE AND GLOBAL ZERO
}

\author{
Anne Finger ${ }^{1}$ \\ Institute for Peace Research and Security Policy (IFSH)
}

\begin{abstract}
:
Most European countries continue to rely on nuclear weapons to ensure their security, as recently confirmed by NATO's new Strategic Concept and the Defence and Deterrence Posture Review (DDPR). Given the persisting nuclear dangers and the risks of a multinuclear world, this article makes the case that the European states should instead take measures to create the conditions for complete nuclear disarmament - regardless whether this goal is achievable or not. This article hence explores the possibilities for a stronger European contribution to the process towards Global Zero, putting forward some recommendations.
\end{abstract}

Keywords: Global Zero, European Union, nuclear non-proliferation, NPT, nuclear deterrence, France, UK.

\section{Resumen:}

La mayoría de los países europeos siguen dependiendo de las armas nucleares para garantizar su propia seguridad, tal y como vimos recientemente confirmado en el nuevo Concepto Estratégico de la OTAN y la Revisión de la Postura de la Disuasión Nuclear (DDPR en sus siglas en inglés). Dados los persistentes peligros nucleares y los riesgos de un mundo multi-nuclear, este artículo argumenta que los estados nucleares deberían al contrario tomar las medidas necesarias para crear las condiciones para un desarme nuclear completo - independientemente de que ese objetivo sea alcanzable o no. Este artículo por tanto explora las posibilidades para una mayor contribución Europea al proceso de "Cero Global", proponiendo con ello ciertas recomendaciones.

Palabras clave: Cero Global, Unión Europea, no proliferación nuclear, TNP, disuasión nuclear, Francia, Reino Unido.

Copyright (C) UNISCI, 2012.

Las opiniones expresadas en estos artículos son propias de sus autores, y no reflejan necesariamente la opinión de UNISCI. The views expressed in these articles are those of the authors, and do not necessarily reflect the views of UNISCI.

\footnotetext{
${ }^{1}$ Anne Finger is a Researcher at the Institute for Peace Research and Security Policy at the University of Hamburg.

E-mail: finger@ifsh.de.

http://dx.doi.org/10.5209/rev_UNIS.2012.n30.4070
} 


\section{Introduction}

The Wall Street Journal op-ed by George Shultz, William Perry, Henry Kissinger and Sam Nunn of January 2007, followed by the April 2009 speech in Prague by US President Barack Obama, have inspired a worldwide debate on 'Global Zero', the complete elimination of all nuclear weapons. ${ }^{2}$ Recently, this debate has become increasingly confrontational, polemical, and tinged with emotion. Instead of focusing on the next concrete steps on the agenda, contributors to the debate argue passionately with each other whether the last steps of total nuclear elimination can be taken or not, and, for example, whether virtual arsenals could be maintained sustainably, amounting in the end to ideological turf battles on whether global zero is 'desirable', 'feasible', 'illogical' or a 'normative imperative'. ${ }^{3}$ Europe's many constituencies with regard to nuclear weapons - nuclear weapon states (NWS) and nonnuclear-weapon states (NNWS), disarmers and deterrers, NATO and the EU - have reacted in a variety of fashions, contributing to the fruitlessness of the debate.

This article makes the case for a stronger European contribution to Global Zero. Nevertheless, it concedes that a common European position towards the complete disarmament of nuclear weapons is unlikely in the near future. It maintains, however, that aiming at Global Zero is in the security interest of all European countries no matter whether they support the idea of total nuclear abolition or not, therefore stressing the importance of the process rather than the final goal. This does not mean agreeing with the proposition of some that the 'Global Zero' idea itself is damaging to the goal of disarmament. Instead, it requires recognition that achieving sustainable security in Europe is not self-evident but needs to be continuously renegotiated and strengthened, and adapted to changing security environments and threat perceptions. This is a process involving NATO, the EU, single European states and groupings of states. The 'Global Zero' process engages these actors around a number of key questions of common security, and encourages the joint resolution of contemporary problems.

The article begins with reasons why aiming at Global Zero is useful to strengthen European security, and briefly outlines the steps most often identified as necessary in the 'Global Zero' process. It then discusses the diverging European positions concerning nuclear weapons and nuclear disarmament. Finally, it identifies existing and potential European contributions to the necessary next disarmament steps and near-time measures, asking what the nuclear states and what the non-nuclear states can contribute. It approaches these questions from the perspectives of single states, groupings of states, NATO, and the EU.

\section{Persisting Nuclear Threats - Why Aiming at Global Zero Makes Sense}

After a short period of optimism in the early 1990s, states have grown to realize that although the Cold War is over and the security environment in Europe has changed fundamentally,

\footnotetext{
${ }^{2}$ Shultz, George P.; Perry, William J.; Kissinger, Henry A. and Nunn, Sam: "A World Free of Nuclear Weapons", Wall Street Journal, 4 January 2007; Obama, Barack: "Remarks by President Barack Obama", Prague, (5 April 2009), at http://www.whitehouse.gov/the_press_office/Remarks-By-President-Barack-ObamaIn-Prague-As-Delivered.

${ }_{3}$ Daalder, Ivo and Lodal, Jan: "The Logic of Zero: Toward a World Without Nuclear Weapons", Foreign Affairs, vol. 87, no. 6 (Nov./Dec. 2008), pp. 80-95; Rydell, Randy: “The Future of Nuclear Arms: A World United and Devided by Zero", Arms Control Today, vol. 39, no. 3 (April 2009), at http://www.armscontrol.org/act/2009 04/Rydell; Tertrais, Bruno: "The Illogic of Zero", The Washington Quarterly, vol. 33, no. 2 (April 2010), pp. 125-138.
} 
nuclear threats continue to exist and have in some significant ways intensified. While the threat of a major nuclear exchange between Russia and the US is much less likely, for example, ongoing conflict between nuclear-armed India and Pakistan still has the potential to escalate to nuclear use. (In its nuclear doctrine at least India calculates on being able to absorb a nuclear strike on the own territory ${ }^{4}$ ). Once a regional conflict has gone nuclear, the risk of further nuclear escalation due to misperceptions or perceived existential threats rises. Especially in countries like the US or Russia with combined arsenals of more than 20,000 nuclear weapons - including many operational warheads on permanent alert status ${ }^{5}$ - the possibility of an unintended, unauthorised or accidental launch of a nuclear device cannot be ruled out. Furthermore, breaches of the Non-Proliferation Treaty (NPT), unstable global and regional security environments, and the unclear ambitions of countries like North Korea and Iran, combined with a widespread diffusion of nuclear materials and technologies, may create incentives for further nuclear proliferation. Finally, the threat of nuclear terrorism has become more urgent due to huge remaining stockpiles of nuclear material, a global black market of nuclear materials and technologies, as well as insufficient security of civil and military nuclear facilities.

In a world of multiple nuclear weapon states, familiar concepts of mutual deterrence would be unlikely to work reliably. ${ }^{6}$ Even leaving the threat of proliferation aside, the key Cold War security threat which led to the establishment of extended nuclear deterrence in Europe, and which contributed to the maintenance of Europe's two national nuclear arsenals namely, Soviet superiority in conventional forces - is no longer present. Moreover, Cold War models of nuclear deterrence are widely perceived to be in need of updating, with the aim of moving towards safer and more stable forms of deterrence. According to Kissinger, Perry, Shultz and Nunn's March 2011 op-ed, "The U.S. and its NATO allies, together with Russia, must begin moving away from threatening force postures and deployments, including the retention of thousands of short-range battlefield nuclear weapons."

Current nuclear arsenals, particularly those of the US and Russia far exceed what is necessary for a credible nuclear deterrent. Sizeable numerical reductions in those arsenals would reduce existing nuclear risks. How further disarmament might be tackled has been the object of new debates and studies, most stressing the necessity of a step-by-step approach. ${ }^{7}$ Four basic steps can be identified ${ }^{8}$ :

\footnotetext{
${ }^{4}$ Sidhu, Waheguru Pal Singh: "India”, in Born, Hans; Gill, Bates and Hänggi, Heiner (eds.) (2010): Governing the Bomb: Civilian Control and Democratic Accountability of Nuclear Weapons, New York, Oxford University Press, pp. 171-194, p. 194.

${ }^{5}$ The US currently has around 1000 nuclear warheads on alert - on land-based intercontinental ballistic missiles (ICBMs) and submarine-launched ballistic missiles (SLBMs). See EastWest Institute (ed.) (2009): "Reframing Nuclear De-Alert. Decreasing the operational readiness of U.S. and Russian arsenals", New York, EastWest Institute, p. i.

${ }^{6}$ Sagan, Scott D.: "More will be worse", in Sagan, Scott D. and Waltz, Kenneth N. (eds.) (2003): The Spread of Nuclear Weapons: A Debate Renewed, $2^{\text {nd }}$ ed., New York/ London, W. W. Norton \& Company, pp. 46-87.

${ }^{7}$ See for example Perkovich, George and Acton, James M. (eds.) (2009): Abolish Nuclear Weapons. A Debate, Carnegie Endowment for International Peace; Goodby, James E.: “A world without nuclear weapons: fantasy or necessity?", in Cruickshank, D.A.; Fox, Joey; Borg, Jetta Gilligan and Trimmer, Caspar (eds.) (2010): SIPRI Yearbook 2010: Armaments, Disarmament and International Security, New York, Oxford University Press, pp. 17-34; Evans, Gareth and Kawaguchi, Yoriko (eds.) (2009): Eliminating Nuclear Threats: A Practical Agenda for Global Policymakers, International Commission on Nuclear Non-proliferation and Disarmament, Canberra, Paragon.

${ }^{8}$ See for example Holloway, David: “The Vision of a World Free of Nuclear Weapons", in Kelleher, Catherine McArdle and Reppy, Judith (eds.) (2011): Getting to Zero - The Path to Nuclear Disarmament, Stanford, University Press, pp. 11-26.
} 
It is generally agreed that the process must begin with further bilateral disarmament by Russia and the United States. Expert studies show how both countries could reduce their nuclear warheads first to a thousand each, simultaneously limiting the associated delivery systems to a few hundred. At a second stage the other existing nuclear weapon states need to be included and a multilateral approach and agreement will have to be developed. While the US and Russia further reduce their arsenals to a few hundred warheads, the other nuclear weapon states would commit themselves firstly to refrain from enlarging their arsenals, and secondly to reduce their stockpiles in proportion to the great powers. At the same time, a comprehensive verification system would need to be built up, and the security of the civil use of nuclear energy improved, especially the storage of nuclear materials.

At a third stage a treaty to completely disarm the last remaining nuclear weapons will need to be negotiated and signed by all relevant states. Final elimination would again take place proportionally, and under close monitoring. In a fourth stage the achievement of complete nuclear disarmament would need to be permanently stabilized. To prevent the regeneration of nuclear weapons, the verification system would need to be further conducted and further developed, adapting to changing conditions.

The feasibility and desirability of such a process is a matter for considerable debate. However, even without supporting the total abolition of nuclear weapons, most measures and ancillary agreements proposed of the first stages are in the interest of all European countries and often already form part of existing strategies and policies. Europe is directly affected by today's persisting nuclear threats; European countries are implicated as users and providers of nuclear technologies and materials, and through the reliance by many states - to varying extents - on nuclear weapons in their security strategies.

At the same time, because civil nuclear and nuclear-weapon states undertake a broad array of related research, they possess the necessary tools to contribute to the next steps in disarmament and to complementary measures. Confidence building and transparency measures will be crucial: nuclear issues, especially in their military aspects, are as much influenced by political thinking as by military and technical considerations. By increasing confidence in the reliability and trustworthiness of opposing actors, European states can create the first steps in enabling further cooperation, e.g. on the nuclear fuel cycle, nuclear security, or the verification of disarmament. Quite apart from the intrinsic benefits of disarmament, Europe as whole can benefit along the path to transparency, technical cooperation, and greater stability.

\section{European Divergence on Disarmament}

The conditions for Europe to forge a common position on nuclear disarmament are not favourable. With two nuclear weapon states, a further five states hosting US tactical weapons on their ground and a few states strongly favouring nuclear disarmament, national positions and interests in Europe differ considerably.

\subsection{The Nuclear Weapons States}

The governments of the two European Nuclear Weapons States, France and the UK, both argue they regard their nuclear weapons as an essential protection against possible future threats. At the same time, both countries emphasise that they have significantly reduced their 
nuclear arsenals since the end of the East-West conflict; that they were among the first countries having signed the Comprehensive Nuclear Test Ban Treaty (CTBT); and that they promote the negotiation of a Fissile Material Cut-off Treaty (FMCT). However, both countries are also undertaking essential modernization of their arsenals to ensure their safety and reliability for the next decades to come.

\subsubsection{France}

As former French president Nikolas Sarkozy reaffirmed in his speech at Cherbourg in 2008, France bases its concept of deterrence on the principle of strict sufficiency. ${ }^{9}$ Government officials claim that France has always maintained "its nuclear arsenal at the lowest possible level, compatible with the strategic context." ${ }^{\text {"Th }}$ Thus far, the newly-elected president François Hollande has reaffirmed his government will uphold the French nuclear deterrent as an essential element of national sovereignty. ${ }^{11}$ Any first hints on possible changes in France's security and defence policy in general might be provided by the new White Paper on Defence and National Security scheduled for the beginning of 2013.

France officially argues that considerable nuclear disarmament has been undertaken since the end of the East-West conflict and that all its remaining nuclear weapons are strategic weapons. ${ }^{12}$ During her EU presidency in 2008, France engaged in developing the EU action plan on disarmament (see below) in the run-up to the 2010 NPT Review Conference, and presented it as evidence of a commitment to disarmament. France has stopped nuclear testing and dismantled her facilities for the production of fissile materials for nuclear weapons at Pierrelatte and Marcoule, and invited international experts to observe the deconstruction. Since the dismantlement of France's ground-to ground component from 1996-1998 (short range mobile missiles and strategic missiles stationed at the Plateau d'Albion) the country's nuclear deterrent only consists of an airborne and a sea-based component. The sea-based component (the core strategic nuclear deterrent) has been reduced to four nuclear-powered submarines (SSBNs) and 48 submarine-launched ballistic missiles (SLBMs). ${ }^{13}$ In 2008, Sarkozy announced that the airborne component would be reduced by one third, and declared that the French arsenal would by then consist of fewer than 300 total warheads. ${ }^{14}$ At the time of his speech, the airborne component had already been reduced: the Jaguar and Mirage IIIborne AN52 nuclear bombs had been decommissioned and dismantled and the Mirage IV strategic aircraft withdrawn from nuclear missions. ${ }^{15}$ Currently, France has available two air force squadrons of nuclear-capable fighter bombers and a small unit of navy fighter bombers,

\footnotetext{
9 Sarkozy, Nicolas: "Presentation of SSBM "Le Terrible" - Speech by M. Nicolas Sarkozy, President of the Republic", Cherbourg (21 March 2008), at http://www.ambafrance-uk.org/President-Sarkozy-s-speechat, 10430.html.

${ }^{10}$ Danon, Eric: "France and nuclear disarmament", Statement by Eric Danon, Permanent Representative of France to the Conference on Disarmament (25 October 2011), at http://www.diplomatie.gouv.fr/en/globalissues/disarmament-arms-control/arms-control-and-arms-trade/implementation-of-disarmament/france-andnuclear-disarmament/article/general-assembly-1st-committee.

${ }^{11}$ See the confirmation of the Minister of Defense Le Drian, Jean-Yves: "Hollande maintiendra la dissuasion", Le Figaro, 14 July 2012, at http://www.lefigaro.fr/flash-actu/2012/07/14/97001-20120714FILWWW00218hollande-maintiendra-la-dissuasion.php.

$\frac{1}{12}$ Tertrais, Bruno: "The Last to Disarm? The Future of France's Nuclear Weapons", Nonproliferation Review, vol. 14, no. 2 (July 2007), pp. 251-273; 255.

${ }^{13}$ Tertrais, Bruno: "France", in Born, Hans; Gill, Bates and Hänggi, Heiner (eds.) (2010): Governing the Bomb: Civilian Control and Democratic Accountability of Nuclear Weapons, New York, Oxford University Press, pp. $103-127$.

${ }^{14}$ Sarkozy, op. cit.

15 Ministère de la Denfense: Nuclear disarmament: France's concrete commitment, at http://www.diplomatie.gouv.fr/en/IMG/pdf/desarmement_nucleaire_France.pdf.
} 
armed with nuclear tipped cruise missiles and dedicated to the aircraft carrier Charles de Gaulle. ${ }^{16}$ However, alongside these reductions, France has begun to significantly modernize the remaining nuclear forces involving submarines, aircraft, missiles, and warheads.

The French Strategic Air Forces (Forces Aériennes Stratégiques (FAS)) is replacing the old nuclear-capable Mirage 2000N K3 aircraft with the new Rafale F3. ${ }^{17}$ The Rafales are also equipped with a new cruise missile (Air-Sol Moyenne Portee Amélioré (ASMPA) with a new warhead (Tête Nucleaire Aéroportée (TNA). ${ }^{18}$ ("The aircraft carrier Charles de Gaulle is equipped to carry ASMPA cruise missiles for delivery by Rafale MF3 fighter bombers." ${ }^{19}$ The same applies to the sea-based nuclear forces. The French Force Océanique Stratégique (FOS) consists of four Triomphant-class nuclear-powered ballistic missile submarines (SSBNs) equipped with nuclear-armed long-range ballistic missiles (SLBMs). At least two of the four SSBNs are always operational, one of them patrolling at sea. The SSBN force is about to be upgraded from the M45 to the M51 missile. Carrying the same warhead (TN75) following EADS compared to the M45 the M51 "offers significantly greater range and payload capacity, as well as greater accuracy." ${ }^{20}$ Lastly, the French nuclear weapons complex - its production facilities and research centres - is undergoing considerable modernization.

France's nuclear doctrine has stayed mostly unchanged since the end of the Cold War. Although France returned into the integrated military structure of NATO in 2009 (after having left in 1966), France decided not to participate in the Nuclear Planning Group of the alliance, wanting her nuclear deterrent to remain entirely independent. An independent nuclear deterrent is regarded as essential to ensure the country's security and freedom of action: "[...] our national independence and decision-making autonomy are preserved [...] Nuclear deterrence is the ultimate guarantee of that." 21 France needs to "remain master of her destiny" facing a "more unstable, more changing, more complex" world and therefore must not "find herself unarmed in the face of a strategic surprise". ${ }^{22}$ The former president Sarkozy concluded: "I absolutely reject the idea of lowering our guard". ${ }^{23}$ Meanwhile, it is French declaratory policy that her nuclear deterrent is "strictly defensive" and would only be used in "extreme circumstances of legitimate defence". ${ }^{24}$ However, France nuclear doctrine does allow for the possibility of sending "a nuclear warning" to underscore the country's resolve and to re-establish deterrence in case "vital interests" are threatened. ${ }^{25}$

However, France announced the de-targeting of her nuclear weapons in 1997, which since has been reaffirmed on several occasions. In his speech at Cherbourg the former president Sarkozy declared: "When international security improves, France draws the consequences [...] I can confirm that none of our weapons are targeted against anyone."26

\footnotetext{
${ }^{16}$ Tertrais, "France...", op. cit., p. 111.

${ }^{17}$ For more details as dates of replacement, combat ranges and tanker fleet see Kristensen, Hans: "France" in Acheson, Ray (ed.) (2012): Assuring Destruction Forever. Nuclear Weapon Modernization around the World, New York, Reaching Critical Will, pp. 27-33, p. 28.

${ }^{18}$ Ibid., p. 29.

${ }^{19}$ Ibid., Idem.

${ }^{20}$ EADS French MSBS Programmes (Submarine-Launched Ballistic Missiles), Le Bourget (13 June 2005), at http://www.eads.com/eads/int/en/news/press.en_20050613_MSBS.html.

${ }^{21}$ Sarkozy, op. cit.

${ }^{22}$ Ibid.

${ }^{23}$ Ibid.

${ }^{24}$ Ibid.

${ }^{25}$ Tertrais, "The Last to Disarm?...” op. cit., pp. 255-256.

${ }^{26}$ Sarkozy, op. cit.
} 
Though announced to be de-targeted, the nuclear weapons remain on alert status, yet it was lowered in 1992 and in 1996, in terms of the forces' responsiveness and the number of weapon systems.

France seems to reject further reductions in the near-term future ${ }^{27}-$ military planning and modernization indicate that no change can be expected in the next 10-20 years to come. Paris is sceptical ${ }^{28}$, if not dismissive, of a complete elimination of nuclear weapons. Moreover, France seems to remain reluctant to even discuss her nuclear weapons, let alone their disarmament, in a multilateral context. With regard to the NATO Weapons of Mass Destruction Control and Disarmament Committee French officials repeatedly argued "that NATO is not the best place to discuss arms control and disarmament issues". ${ }^{29}$

\subsubsection{The United Kingdom}

The UK's stated nuclear policy is one of 'minimum deterrence'. Since the withdrawal of the last WE-177 gravity bomb in 1998, the UK has maintained a single nuclear delivery system Trident II D5 submarine-launched ballistic missiles - with a single warhead type. The UK maintains a posture of 'continuous at-sea deterrence', meaning that one Trident-armed submarine (SSBN) is always on patrol, from a fleet of four boats; the missiles themselves are de-targeted, and on several days' notice to fire. ${ }^{30}$ The UK's 2010 Strategic Defence and Security Review - whilst reaffirming the incoming government's decision to pursue renewal of the SSBN fleet - continued a process of downward adjustment in stockpile numbers and posture that has been ongoing since the Cold War. Specifically, it provided a negative security assurance - a commitment not to use or threaten to use nuclear weapons - to non-nuclearweapon state signatories to the NPT in good standing with their non-proliferation obligations; announced a reduction in the overall warhead stockpile to 180 from 225 , a number first revealed a few months earlier, at the 2010 NPT Review Conference, and a reduction in the requirement for operationally available warheads from 160 to 120; and a reduction in the number of operational missiles on each SSBN to no more than eight. ${ }^{31}$

The UK has also been relatively active in the field of arms control. In policy terms, the government engaged in outreach in the run-up to the 2010 NPT Review Conference, emphasising the role of disarmament progress in renewing the treaty's 'grand bargain'. ${ }^{32} \mathrm{UK}$ officials were also among the first senior nuclear-weapon-state representatives to endorse the 'new wave' of disarmament advocacy following the 2007 'gang of four' op-ed, most notably in the shape of Foreign Secretary Margaret Beckett's speech to the Carnegie Endowment NonProliferation Conference in June 2007, and Defence Secretary Des Browne's speech to the Conference on Disarmament in February 2008. ${ }^{33}$ In technical terms, in 1998 an arms control

\footnotetext{
${ }^{27}$ Kristensen, op. cit., p. 27.

${ }^{28}$ Tertrais, "France...", op. cit., p. 126.

29 Meier, Oliver: "NATO Sticks with Nuclear Policy", Arms Control Association (June 2012), at http://www.armscontrol.org/act/2012 06/NATO_Sticks_With_Nuclear_Policy.

${ }^{30}$ House of Commons: "Strategic Defence Review White Paper", Research Paper 98/91 (October 1998), paragraph 68 .

31 "Securing Britain in an Age of Uncertainty: The Strategic Defence and Security Review", CM 7948 (October 2010), London, HMSO, pp. 37-38.

${ }^{32}$ See UK Cabinet Office (2009): The Road to 2010: Addressing the nuclear question in the twenty first century, CM 7575, London, HMSO, pp. 30-42.

${ }^{33}$ Beckett, Margaret: "A World Free of Nuclear Weapons?", address to the Carnegie International Nonproliferation Conference (25 June 2007), at http://www.carnegieendowment.org/2007/06/25/keynoteaddress-world-free-of-nuclear-weapons/kc0; Browne, Desmond H.: "Laying the Foundations for Multilateral Disarmament", address to the Conference on Disarmament (5 February 2008), at
} 
verification research programme was set up at the Atomic Weapons Establishment in Aldermaston, and from 2007-2010 the UK and Norway collaborated on an exercise to simulate a non-nuclear-weapon state verifying warhead dismantlement by a nuclear-weapon state, the results of which have been briefed to non-nuclear-weapon states, and to the other nuclear-weapon states as part of the ongoing P5 dialogue on confidence-building measures in support of nuclear disarmament. ${ }^{34}$

\subsection{Non-Nuclear Weapon States - Members of a Nuclear Alliance}

Any 'European' approach to disarmament in theory is made more complicated in practice because most European states are NATO members. NATO as a whole, Europe's most important security organization, remains a "nuclear alliance" 35 . The nuclear component was confirmed as a core element of the alliance' defence and deterrence concept by the Strategic Concept of 2010 and the Defence and Deterrence Posture (DDPR) completed in 2012.

At the same time, some NATO states do lean further towards nuclear disarmament, and there are especially sharp divisions over the status of the remaining US tactical nuclear weapons (TNW) in Europe. US extended deterrence in Europe is provided by US strategic nuclear weapons and forward based TNW. There are approximately 180 B-61 gravity bombs at air bases in Belgium, Germany, Italy, the Netherlands and Turkey, for delivery by US and host countries' aircraft. ${ }^{36}$ This situation puts the European non-nuclear weapon states in a difficult position. Those states that host the infrastructure and aircraft to deliver the US B-61s will have to take a decision in the next few years whether or to modernize existing aircrafts (or make the Eurofighter dual capable), as existing means of delivery are ageing. An additional source of political pressure derives from the US life extension programme for the B-61s which, if completed, will lead to the stationing of modernized and more capable nuclear weapons from 2019.

After NATO's new strategic concept was decided in November 2010 the Alliance debated for more than a year and a half about the appropriate mixture of means to best achieve security for NATO members in the future. In its Strategic Concept, NATO continues to base its deterrence on nuclear and conventional capabilities and retains its first-use option. The Concept states "as long as there are nuclear weapons in the world, NATO will remain a nuclear alliance". ${ }^{37}$ Any further disarmament steps in relation to TNW are linked to reciprocal Russian steps. However, the concept in general welcomes the aim of a nuclear weapons-free world. The DDPR reaffirmed nuclear weapons as a core component of NATO's overall capabilities for deterrence and defence alongside conventional forces and named missile defence forces as third complementary component. ${ }^{38}$ Although it also called for NATO members to reduce the reliance on TNW based in Europe, this does not seem to mean a "significant departure from the existing perspective on nuclear sharing arrangements." 39 However, the DDPR does provide a mandate for future confidence building talks with Russia

http://www.labour.org.uk/des browne conference on nuclear_disarmament.

${ }_{34}$ See, UK presentation to 2012 NPT Prepcom (May 2012), at http://www.mod.uk/NR/rdonlyres/F5E721E4C2BF-424A-8A51-A75182535012/0/20120503 npt_prepcom_presentation.pdf.

${ }^{35}$ NATO: "Active Engagement, Modern Defence. Strategic Concept" (20 November 2010), p. 5, at http://www.nato.int/strategic-concept/index.html.

${ }^{36}$ Norris, Robert S. and Kristensen, Hans M.: "US tactical nuclear weapons in Europe", Bulletin of the Atomic Scientists, vol. 67, no. 1 (2011), pp. 64-73;64-66.

${ }^{37}$ NATO, “Active Engagement...", op. cit., p. 5.

${ }^{38}$ NATO: "Deterrence and Defence Posture Review", 20 May 2012, paragraph 8, at http://www.nato.int/cps/en/natolive/official texts 87597.htm.

${ }^{39}$ Meier, "NATO Sticks...", op. cit. 
on TNWs, aiming "to develop and exchange transparency and confidence-building ideas with the Russian Federation in the NATO-Russia Council [...]." ${ }^{40}$ It remains to be seen what form and what authority the follow-up arms control committee (replacing the provisional Weapons of Mass Destruction Control and Disarmament Committee) will be attributed. While France seems to want to limit its competence and in general holds that NATO is not the right forum to discuss disarmament, one Polish official has predicted that the committee "will try to build its own identity and expand its role, including a general discussion of what role NATO can play in arms control and disarmament. ${ }^{41}$ Of the European countries in favour of a withdrawal of TNW from Europe, Germany (a host country) is most prominent in demanding action. Berlin argues that the remaining TNW are of no longer of any military use, that US engagement in Europe does not rely on extended deterrence and that in practice extended deterrence is provided entirely by the United States' strategic weapons. The supporters of withdrawal also argue that withdrawal would bring positive momentum to NATO-Russia relations. In Germany there is a broad consensus across all major political parties that the remaining US TNW in Europe should be withdrawn. Initiated by the Liberal Party (FDP), this position was even part of the coalition agreement of the Christian Democratic Party (CDU) and the FDP on its entry into power in 2009. The host countries Belgium and the Netherlands seem to have similar positions but did not push for a decisive change during the discussions on NATO's New Strategic Concept and the DDPR.

In contrast to most of the host countries, the majority of the eastern and central European NATO members oppose a (unilateral) withdrawal of US tactical nuclear weapons in the near future. They are concerned about future US engagement in Europe within NATO and want to keep a strong link through extended deterrence; they also regard the remaining US TNW as a bargaining chip with regard to future negotiations with Russia and insist on reciprocal steps for any NATO withdrawal (a principle supported in the DDPR).

The remaining non-nuclear-weapon states, although not necessarily strongly attached to the tactical nuclear weapons, appear to prioritise alliance coherence over progress in disarmament. Their desire not to rock the boat unnecessarily may well have been a crucial factor in the status quo outcome of the DDPR.

\subsection{European Union}

The European Union's efforts to develop and strengthen a common non-proliferation policy with regard to nuclear weapons have been irresolute and somewhat ineffective. Due to the variety of positions and interests, unfortunately, it is even more difficult to take effective and concerted actions to work towards nuclear disarmament.

\subsubsection{EU 2003 Strategy against the Proliferation of WMDs}

Nevertheless, in 2003, the EU adopted a strategy against the proliferation of weapons of mass destruction that includes at least measures meant to enable further nuclear disarmament. The strategy is mainly being implemented through contributions to existing organisations and projects (including support to the IAEA, CTBTO, OPCW, Security Council Resolution 1540 and the Hague Code of Conduct against Ballistic Missile Proliferation), and by adding a nonproliferation clause to agreements between the EU and third countries.

\footnotetext{
${ }^{40}$ NATO, "DDPR...", op. cit., paragraph 25.

${ }^{41}$ Meier, "NATO Sticks...", op. cit.
} 


\subsubsection{EU 2008 Declaration and Action Plan for Disarmament}

In December 2008, during the French EU-presidency, EU heads of state and government endorsed a declaration on tighter international security. Building further on the strategy against the proliferation of weapons of mass destruction, the declaration includes an action plan focusing on issues related to disarmament, non-proliferation of weapons of mass destruction and their means of delivery as well as the prevention of terrorism. ${ }^{42}$

Agreed in the run-up to the 2010 NPT Review Conference, the actions called for are on the whole a repetition of broadly shared, lowest common denominator positions. They include general support for a global reduction of the world's nuclear arsenals in accordance with Article VI of the NPT and the establishment of confidence-building and transparency measures by the nuclear powers. All states are called to accede to the CTBT, to complete its verification regime, and to verifiable dismantle all nuclear testing facilities; to start negotiations on a fissile material cut-off treaty (FMCT) and introduce an immediate moratorium on the production of such material. Notably, the document also calls on states that possess tactical nuclear weapons to include them in negotiations on arms control and disarmament to reduce and eliminate them ${ }^{43}$ - a position that has been controversial within the NATO framework during the last couple of years, as discussed above. An overview of the EU activities in implementing the EU Strategy against the Proliferation of WMD is to be provided by a six-monthly progress report. ${ }^{44}$

\section{Recommendations - Possible Future European Contributions to Nuclear Disarmament}

Potential European contributions to progress in nuclear disarmament are best differentiated in two respects: firstly, by actor (nuclear weapon and non-nuclear weapon single states and multi-state groupings, NATO, EU); and secondly, for each actor, by type - that is to say, direct disarmament or measures involving concrete policy actions necessary for progress in nuclear disarmament, but not involving the actual withdrawal and/or dismantlement of weapons; finally some measures develop the capabilities and broader conditions for disarmament to take place.

\subsection{Individual States}

\subsubsection{The Nuclear Weapon States}

Give the current modernization of its nuclear arsenal, it is unlikely that France will reduce its nuclear arsenal a great deal further than already planned in the near future. Nevertheless, it would be desirable if France could be convinced to reduce her arsenal to a limit similar as the one of the UK. Not only does France have about twice as many warheads available as the UK,

\footnotetext{
${ }^{42}$ For details of the Strategy, its rationale and the action plan see, Portela, Clara: "The EU and the NPT: Testing the New European Nonproliferation Strategy", Disarmament Diplomacy, vol. 78 (July-August 2004), at http://www.acronym.org.uk/dd/dd78/78cp.htm.

${ }^{43}$ See information provided by the French Ministry of Foreign Affairs, at http://www.diplomatie.gouv.fr/en/IMG/pdf/desarmement_nucleaire_France.pdf.

${ }^{44}$ See latest "Six-monthly Progress Report on the implementation of the EU Strategy against the Proliferation of Weapons of Mass Destruction (2012/C 66/03)", at http://www.consilium.europa.eu/media/1688127/2011_ii_wmd_progress_report.pdf.
} 
but around one-fifth of the French arsenal consists of airborne stand-off weapon. Even the new ASMPA missiles for delivery by the Rafale MF3 fighter bombers have a maximum range between 2,000 and 2,750 kilometres. Although defined by France as strategic, countries such as the US and Russia would count them as tactical weapons. The disarmament of the remaining airborne component and a restriction of nuclear deterrence to submarine-launched strategic nuclear weapon, similar to the UK, would therefore be an important step towards a safer and more stable form of deterrence.

The question of whether UK will maintain the nuclear deterrent in its current form is not entirely settled. Although several long-lead procurement decisions have been taken in support of a like-for-like replacement of Trident, the 'main gate' decision to build a new fleet of SSBNs has been postponed until 2016 (that is to say, after the next election), and the politics of the Conservative-Liberal Democrat coalition formed in 2010 have led to a Cabinet Office review of options, considering alternative delivery vehicles and alternative nuclear postures. Although the most likely outcome appears at this stage to be a like-for-like renewal of Trident, the possibility of further partial or even full unilateral disarmament cannot be totally excluded, given the economic pressures on the British government. The 'main gate' Trident decision, plus the decision, due in the next Parliament, on the next-generation British warhead, are likely to be highly controversial, and may play a role in campaigning in the next general election. Lastly, the possibility of Scotland - where the SSBN fleet is based, at Faslane - voting for independence from the United Kingdom (although, again, relatively unlikely) has raised additional complications for the UK retaining its nuclear forces. ${ }^{45}$

Apart from disarming themselves, France and the UK can contribute creating the conditions for further disarmament by a range of measures. In particular, being nuclear weapon states, both countries can try to exert influence on the nuclear policies of the other nuclear weapon states.

\section{UK-France Cooperation}

A development having the potential to influence the French position on nuclear disarmament is the intensified nuclear cooperation with the UK. In November 2010, France and the UK signed two treaties for defence and security cooperation. First of all, the treaties aim at converging both countries' armed forces and industries to improve defence capabilities using technological synergies, to optimize investment and allow savings. France declares furthermore "the main objective of this historical rapprochement is to allow France and the United Kingdom to maintain their status of global military powers - despite the reduction of their defence budgets - while retaining their national sovereignty and independence regarding the decision to deploy their own forces."46

While the first treaty deals with defence and security cooperation in general, the second treaty is specific. It concerns the modelling of the performances of nuclear warheads through joint X-Ray and hydrodynamic infrastructures, guaranteeing the functioning of the nuclear arms and their safety. ${ }^{47}$

\footnotetext{
45 see Chalmers, Malcolm and Walker, William (2001): Uncharted Waters: the UK, Nuclear Weapons and the Scottish Question, East Linton, Tuckwell, and more recently Blitz, James: “Scots' breakaway plan threatens nuclear base", Financial Times, 13 January 2012.

${ }^{46}$ For more details see the information provided by the French Embassy to the UK, at http://www.ambafranceuk.org/Defence-cooperation.

${ }^{47}$ Ibid.
} 
At first sight, "a 50-year agreement to cooperate on the science of maintaining a nuclear weapons stockpile in itself hardy indicates progress towards a world free from nuclear weapons". ${ }^{48}$ Out of a French perspective the treaty surely is a means to stay informed about the British nuclear programme and planning and to ensure not to be the only European nuclear weapon state in a foreseeable future. ${ }^{49}$ Moreover, France stresses the cooperation and joint research "absolutely do not call into question the independence of each national deterrence". 50 None the less, to further develop cooperation on military nuclear issues means a loosening of secrecy, more transparency on technologies, a more intensive mooting of doctrines - in general an opening up to influence of the other side on national nuclear politics.

\subsubsection{Non-Nuclear Weapon States}

As nuclear issues are highly sensitive and demand a special degree of trust and secrecy, one sensible route forward is for single European states, or coalitions of a few states, to cooperate with nuclear weapon states to tackle various aspects of disarmament, building on existing levels of trust in their relationships. Two examples for such initiatives shall be given. The first is a proposal for disarming TNW in Europe by the Swedish Defence Agency FOI; second is the UK-Norway initiative on the verification of warhead dismantlement.

\section{The FOI Proposal - A Regional Approach}

In 2011 the Swedish Defence Research Agency FOI published a study proposing a geographically limited approach to remove all TNW from the Baltic area. ${ }^{51}$ The basic idea of the proposal is to start with a verifiable partial withdrawal of warheads ${ }^{52}$ from a number of sites in the region of the south-eastern Baltic Sea. To implement this idea (after having achieved basic transparency and less threatening postures for TNW), arsenals would to be limited through ceilings on numbers, compositions and locations (in a legally-binding treaty) to then sequentially reduce the size of arsenals. The primary parties of such an approach would be the owners of the warheads (Russia and the United States) but the proposal stresses that European NATO member states would also need to be included - particularly nuclear host countries. ${ }^{53}$

The proposal suggests including non-deployed nuclear weapons and production facilities. To lower the barriers to starting with a partial withdrawal, storage facilities might be kept operational under supervision for a certain period: "Important milestones would be to establish transparency regarding the size, composition and location of the respective arsenals,

\footnotetext{
${ }^{48}$ Harries, Matthew: "Britain and France as Nuclear Partners", Survival, vol. 53, no. 1 (February-March 2012), pp.7-30; 20.

Ibid., pp. 20-21; Tertrais, Bruno: "Entente Nucleaire. Options for UK-French Nuclear Cooperation", Discussion Paper 3 of the BASIC Trident Commission (June 2012) p.26, at http://www.basicint.org/sites/default/files/entente_nucleaire basic trident_commission.pdf.

${ }^{50}$ See French Embassy to the UK, at http://www.ambafrance-uk.org/Defence-cooperation.

${ }^{51}$ For all described arms control regimes alternatives see Lindvall, Fredrik; Rydqvist, John; Westerlund, Fredrik and Winnerstig, Mike (2011): The Baltic Approach: A next step?, Stockholm, FOI Swedish Defence Research Agency, pp. 59-71.

${ }^{52}$ An effective arms control regime on TNW has to be based on warheads due to the difficulty in distinguishing conventional weapon carriers from nuclear ones.

53 "Geographically, this alternative would include all or part of the territories of the NATO member states in northern Europe, the western-most part of Russia (roughly equal to the former Leningrad military district) and possibly also Belarus, Finland, Sweden and the Ukraine." Lindvall et al., op. cit., p. 59.
} 
to achieve a less threatening sub-strategic nuclear posture and to limit and subsequently reduce the number of warheads in the designated area." 54

The elegance of the FOI proposal is that initial steps can be voluntary (including inspections and monitoring of storage facilities); they do not oppose the fundamental interests of any party (in the beginning Russia would withdraw warheads of one storage further to the east) or only regard some warheads and facilities of the countries involved. The arms control regime could start small, concerning the geographical scope and the number of actors, and grow step-by-step in extent and degree of verification. Following a similar approach, in the area of administrative and technical aspects of disarmament verification, partnerships between nuclear- and non-nuclear-weapon European countries could provide a major contribution to increasing knowledge and developing solutions in a relatively trusting environment.

\section{The UK-Norway Initiative - A Mixed Coalition}

One model example is the UK-Norway initiative. In 2007, representatives from the UK Ministry of Defence, the UK Atomic Weapons Establishment, several Norwegian laboratories and the Non-Governmental Organisation VERTIC (Verification Research, Training and Information Centre) began a project on the technical verification of nuclear disarmament. The initiative was a novelty in two respects: it was the first time a nuclear weapon state engaged in research in this field with a non-nuclear state, and it was also an unusual instance of exchanging information and cooperating with and NGO as a non-state actor.

In 2010 the initiative published a report on the outcome of three years' collaboration to investigate the technical and procedural challenges associated with a possible future nuclear disarmament verification regime ${ }^{55}$, and in December 2011 the UK and Norway hosted a workshop to further the technical research on nuclear dismantlement verification. The work of the UK-Norway initiative was also highlighted at the NPT Preparatory Committee on 3 May 2012, with a UKNI presentation on the Managed Access Exercise that took place at the UK Atomic Weapons Establishment in 2010 (see above). The profit of such initiatives for a nuclear weapon state is obvious - it provides a possibility to show their commitment with regard to disarmament, fulfilling their NPT Article VI obligations. The NNWS can claim to become a more trusted partner in a highly sensitive issue of national security, credibly testify on the nuclear-weapon state's activities and can lay the foundation for a future multilateral verification system, which will necessarily involve both nuclear- and non-nuclear-weapon states.

In addition to this substantive work, political and military leaders in individual states, nuclear and non-nuclear, can help establish the political foundations for disarmament by making public their support for further reductions, thus lending credibility to such proposals and providing ammunition to their supporters in the United States and Russia. Several op-eds in this direction have been published in the last few years, including in Belgium, Italy, the Netherlands, Germany, Sweden, Poland, and the United Kingdom. ${ }^{56}$

\footnotetext{
${ }^{54}$ Ibid., p. 60.

${ }^{55}$ Norway and the United Kingdom of Great Britain and Northern Ireland (2010): "The United KingdomNorway initiative: research into the verification of nuclear warhead dismantlement", May 2010 (NPT/CONF.2010/WP.41), at http://www.un.org/ga/search/view_doc.asp?symbol=NPT/CONF.2010/WP.41.

56 See Neuneck, Götz: "Is a World without Nuclear Weapons Attainable? Comparative Perspectives on Goals and Prospects", in Kelleher, Catherine McArdle and Reppy, Judith (eds.) (2011): Getting to Zero - The Path to Nuclear Disarmament, Stanford, University Press, pp. 43-66.
} 


\subsection{NATO}

NATO as an alliance cannot directly disarm any nuclear weapons: the weapons assigned to NATO are American and British. Moreover, all member states collectively reaffirmed in the latest DDPR that NATO should stay a nuclear alliance - at least in the next years to come. Nonetheless, the DDPR also contains evidence of the possibility of cautious change. First, the DDPR recognized the importance of arms control, disarmament and non-proliferation for the alliance's security objectives; second it states its resolve to create the conditions for a world without nuclear weapons. ${ }^{57}$ Through the Nuclear Planning Group (NPG) and the follow-up committee of the WMDDC, even non-nuclear members can take influence on common nuclear policy. More broadly, the nature of what it means for NATO to exist as a 'nuclear alliance' is a matter for collective decision. In this sense, all NATO countries may work towards reducing NATO's reliance on (tactical) nuclear weapons and debate and develop safer and more stable forms of deterrence.

Because of internal differences, and especially due to French opposition, NATO at Chicago in 2012 missed an opportunity to adjust its nuclear posture to the more restrained model of the US. It also was not possible to agree on common negative security guarantees. Both measures would at a minimum be of important political and symbolic value.

Such a process of change is only possible if it is accompanied by measures concerning NATO's internal and external relations. Internally, alliance cohesion needs to be strengthened and preserved through non-nuclear means. Especially important is to reassure the central and eastern European states by providing credible NATO security assurances. In addition, some experts have argued that the development of a NATO BMD system could take over certain political functions of nuclear sharing - for example, by creating a tangible and visible link with the United States.

In external terms, relations with Russia need to be improved. Current stagnation has mainly developed over US plans for a ballistic missile defence system and is also hindering common action on other important issues. To prevent further deterioration and escalation, dialogue and cooperation with Russia must be improved. The envisaged transparency and confidence building measures to be negotiated in the NATO-Russia Council (NRC) are therefore a step in the right direction.

NATO (and its component members) can provide political and rhetorical support of further bilateral disarmament by the US and Russia. The necessity for support also applies to non-nuclear issues - the development of a BMD system for Europe and conventional arms control are linked to the role of nuclear weapons, and will be integral to any follow-on bilateral arms control agreement after New START:

\section{Obstacles for Disarmament: Missile Defence and Conventional Capabilities}

Questions of nuclear deterrence cannot be tackled in isolation, and have been linked to nonnuclear issues by the states involved. The US plans for a missile defence system in Europe are perhaps the biggest single problem in the next round of US-Russian nuclear reductions.

NATO officially decided in November 2010, at its summit in Lisbon, "to develop a missile defence capability to protect all NATO European populations, territory and forces."

\footnotetext{
${ }^{57}$ NATO, DDPR, op. cit., paragraphs 22, 24.

${ }^{58}$ NATO: "Lisbon Summit Declaration" (20 November 2010), paragraph 2.
} 
At the Chicago summit in May 2012, NATO announced it "has achieved an Interim Capability for its missile defence." ${ }^{59}$ Furthermore, the DDPR reaffirms missile defence to be a core element of NATO defence alongside its nuclear and conventional capabilities. ${ }^{60}$ Within the NATO-Russia Council, Moscow was asked to cooperate on BMD. The idea stated in Lisbon was "to explore the potential for linking current and planned missile defence systems at an appropriate time in mutually beneficial ways". ${ }^{61}$ In the DDPR NATO repeats the intent to cooperate, stressing "NATO missile defence is not oriented against Russia nor does it have the capability to undermine Russia's strategic deterrent." ${ }^{62}$ So far however, missile defence cooperation with Russia remains primarily a political project and offers of cooperation have been vague and poorly received.

Although presently BMD is mainly a political problem, Russian concerns that in a later phase of the planned European Phased Adaptive Approach (EPAA) Russian strategic nuclear capabilities might be threatened, need to be taken seriously. Indeed, in the actual planned ship-based Aegis BMD system in phase 3 from 2018 will be enabled in principle to intercept longer range ballistic missiles (Intermediate-Range Ballistic Missiles, IRBM) and in phase 4 to intercept intercontinental missiles (ICBM) ${ }^{63}$ The de-escalation of conflict over missile defence in Europe is primarily a US responsibility; nevertheless, European NATO members can influence the discussions through the NRC and when debating the future shape and the European contribution to NATO BMD.

Current analysis and actual debates show that nuclear disarmament is also strongly linked to conventional capacities - at least out of a Russian perspective - meaning that the process of eliminating nuclear weapons cannot stand alone but must be accompanied by measures and agreements limiting conventional weapons. One main reason why Russia is unwilling to reduce its remaining tactical nuclear weapons is NATO conventional dominance. TNW are the only field where Russia has a numerical advantage. Apart from traditional conventional capabilities, as defined and regulated by the CFE, Russia is concerned about the technological superiority of US conventional forces, especially its Conventional Prompt Global Strike (CPGS) Program to develop and build capabilities for conventional strikes with long-range delivery systems and high accuracy. NATO countries will play an important role in defining the possible scope and content of any new initiative in conventional arms control. 64

\subsection{European Union}

The divergence of interests and positions of EU states in security and defence policy, the lack of binding decision-making mechanisms in this field, and the overlapping jurisdiction of NATO on the TNW issue, means that the EU itself cannot undertake direct measures of disarmament, although it can encourage the nuclear weapon states to reduce and eliminate

\footnotetext{
${ }^{59}$ NATO, “DDPR...”, op. cit., paragraph 19.

${ }^{60}$ Ibid., paragraph 8.

${ }^{61}$ NATO, "Lisbon summit...", op. cit., paragraph 38.

${ }^{62}$ NATO, "DDPR...”, op. cit., paragraph 21.

${ }^{63}$ Brzoska, Michael; Finger, Anne; Meier, Oliver; Neuneck, Götz and Zellner, Wolfgang (2011): "Prospects for Disarmament in Europe", FES Study (Nov. 2011), pg.13, at http://library.fes.de/pdf-files/id/ipa/08718.pdf. For more detailed information also see: Alwardt, Christian; Gils, Hans,Christian and Neuneck, Götz: "Raketenabwehr in Europa: Territorialer Schutz oder Hindernis für nukleare Abrüstung?", in Johannsen, Margret; Schoch, Bruno; Hauswedell, Corinna; Debiel, Tobias and Fröhlich, Christiane (eds.) (2011): Friedensgutachten 2011, Berlin, LIT Verlag, pp. 342-354, p. 347.

${ }^{64}$ Brzoska et al., "Prospects for Disarmament...", op. cit., pp. 27-30.
} 
existing stockpiles. The EU's principal contributions to disarmament, therefore, are measures that contribute to create the necessary conditions for disarmament.

\subsubsection{Universalisation of Treaties}

The maintenance of a firm non-proliferation regime is an essential part of any credible disarmament process, and it is probably here that the strongest EU contributions to the next necessary steps can be made. Firstly, continuing "traditional" non-proliferation policy, the EU should further pursue the strengthening of the NPT and related export control agreements, in particular and apply the policy of a general non-proliferation clause when concluding an agreement with third party countries, and it should continue its engagement to universalize the CTBT and to start negotiations on a FMCT (though arguably the focus of both those debates lies elsewhere).

\subsubsection{Multilateral Approaches to the Fuel Cycle}

One measure often proposed as a crucial ingredient in a future disarmament regime is the internationalization of the nuclear fuel cycle. This would remove control of the production of nuclear fuel (and thus control of potential production of fissile material for nuclear weapons) from the hands of individual states, and place it in the hands of a multinational consortium or an international entity.

At a Council meeting in December 2008, the EU adopted conclusions on multilateral nuclear fuel guarantees, in which it is stated that the EU plans to contribute up to EUR 25 million to the establishment of a nuclear fuel bank placed under the control of the IAEA. ${ }^{65}$ The first steps in establishing international uranium enrichment centres have already been taken. ${ }^{66}$ European progress to date in pursuing such approaches suggests that the EU can be a leader in developing the institutions and investment for this section of a future disarmament regime. It is worth noting, though, that significant political obstacles will have to be overcome before such schemes can be realized.

\subsubsection{Security of Civil Nuclear Energy}

Another fundamental aspect to develop the conditions for the secure abolishing of nuclear weapons is the improvement of the security of the civil use of nuclear energy, particularly the safeguarding and monitoring of nuclear materials. However, the difficulty of agreeing even on basic common safety standards with regard to civil nuclear facilities became again apparent in the aftermath of the Fukushima accident. The so called EU 'stress tests' (Comprehensive risk and safety assessments of the EU nuclear power plants), supposed to assess the safety of all

${ }^{65}$ Council of the European Union: "Press Release $2914^{\text {th }}$ Council meeting: General Affairs and External Relations. General Affairs", Press Release 16862 (8 December 2008), at http://www.consilium.europa.eu/uedocs/cms_data/docs/pressdata/en/gena/104617.pdf.

${ }_{66}$ Apart from the first ever International Uranium Enrichment Centre (IUEC) at Angarsk in Siberia (Kaiser, Peter: "Russia Inaugurates World's First Low Enriched Uranium Reserve", IAEA Staff Report (17 Dec. 2010), at http://www.iaea.org/newscenter/news/2010/leureserve.html.), the Eurodif arrangement is pursuing an similar approach: a single large enrichment plant in France with five owners (France - 60\%, Italy, Spain, Belgium and Iran) is operated under IAEA safeguards by the host country without giving participants any access to the enrichment technology. Simply some entitlement to be supplied with low-enriched uranium for power reactors is given - and even that is constrained in the case of Iran. The three-nation Urenco set-up is also similar though with more plants in different countries - the UK, the Netherlands and Germany. The technology is not available to host countries or accessible to other equity holders (Homepage of the World Nuclear Association, at http://www.world-nuclear.org/info/inf28.html). 
147 nuclear power plants run by 14 EU members, the Ukraine and Switzerland ( 38 have been visited), face difficulties and the unwillingness of EU countries to share information. Yet, some improvement has been reached (e.g. with regard to the threat of a plane crash) and more can be said after the EU commission has presented the final report in October 2012 and after the proposal for new guidelines is submitted in $2013 .{ }^{67}$

\subsubsection{Common and Coordinated Research}

The EU can use its economic and scientific and technical resources to develop disarmamentrelated technologies; it can also apply its combined political influence, and its position in world governance, to broader questions of the political conditions necessary to sustain and enforce a future disarmament regime. One crucial area in the former category is verification. Here, the EU can not only coordinate and fund academic and non-governmental activities, but can also carry out research directly, through EU institutions such as the Joint Research Centre $(J R C)$, the science-service of the European Commission. ${ }^{68}$ One other similar measure of potential value if further pursued is the formation in 2011 of an EU Non-Proliferation Consortium, which could harness the combined output of the many European think tanks and academic institutions carrying out disarmament-related research

Common efforts could also be intensified in the area of nuclear forensics - the cluster of techniques used to determine the physical, chemical, elemental, and isotopic characteristics of nuclear (or radiological) material of unknown origin. Nuclear forensic capabilities are a crucial tool in combating the illicit trafficking of nuclear materials, as well as a potential deterrent tool against nuclear terrorism. ${ }^{69}$

\subsubsection{Assistance to NWFZ}

In the political realm, one major area of possible EU support is to help implementing the treaties for existing nuclear-weapon-free zones (NWFZ) and support establishing further NWFZ. With regard to the Pelindaba Treaty, establishing a NWFZ on the African Continent, the EU offered support to establish the Africa Commission on Nuclear Energy (AFCONE) which is responsible for the treaty's verification together with the IAEA. ${ }^{70}$ As many African states claim to not have the financial means to set up necessary monitoring systems and reporting mechanisms, EU should continue to offer cooperation as well as technical and financial assistance in this areas. The EU also has a central role to play in facilitating efforts towards a WMD-free zone in the Middle East.

\footnotetext{
67 "Europaweiter Stresstest noch nicht beendet", Handelsblatt, 26.04.2012, at http://www.handelsblatt.com/politik/international/atomkraftwerke-europaweiter-stresstest-noch-nichtbeendet/6561568.html.

For further details also see the website of the European Commission, at http://ec.europa.eu/energy/nuclear/safety/stress tests_en.htm.

${ }^{68}$ See European Council, at http://ec.europa.eu/dgs/jrc/index.cfm.

${ }^{69}$ See for example, the work of the Institute for Transuranium Elements (ITU) as part of the JRC, homepage at http://itu.jrc.ec.europa.eu/index.php?id=125.

${ }^{70}$ EU General Statement, First Preparatory Committee for the 2015 NPT Review Conference, Vienna (30 April11 May 2012), at

http://www.un.org/disarmament/WMD/Nuclear/NPT2015/PrepCom2012/statements/20120430/European_Union .pdf. The first ordinary AFCONE session was held in May 2011, the second in July 2012. See conclusions of the first meeting; "First Ordinary Session of the African Commission on Nuclear Energy (AFCONE)", (4 May 2011), at http://www.keepandshare.com/doc/2844929/afcone-1st-ordinary-session-conclusions-en-pdf-june-12011-10-31-am-92k?dn=y\&dnad=y.
} 


\section{Conclusions: Efforts of All Versus Common Effort}

An overview of national positions regarding nuclear disarmament and the policies of NATO and the EU shows that there are some measures towards a world without nuclear weapons that can not only be taken but have already begun. Pursuing them further offers potential benefits to European security interests, even if there remain disagreements about the desirability of the final goal. However, as has been explored above, the key obstacles to progress relate to the manner in which European security interests are defined, and the need to proceed by consensus within a number of overlapping constituencies. There are five broader conclusions that can be drawn from this analysis:

First a single, comprehensive, and ambitious European approach on nuclear disarmament cannot be expected in the next future. Currently, neither the EU nor NATO can be the driving force: the EU does not have the mandate; NATO has to balance the contradicting interests of its members. Being a nuclear alliance, though, also brings the responsibility of continuously reassessing nuclear policy and ensuring it does not contain unnecessarily threatening force postures and deployments. Therefore, the alliance's declaration to further engage in the field of arms control, non-proliferation and disarmament and to continue committing a working group on these questions is crucial.

Second, nuclear disarmament touches on core issues of national security and sovereignty: this implies that it has to be mostly single states or coalitions of states that can most successfully tackle the aspects that are military sensitive. Coalitions of nuclear and nonnuclear weapon states can draw complementary benefits. Nuclear weapon states open up to cooperation in an area of strict secrecy, provide the necessary know-how and show commitment to working towards disarmament. Non nuclear states can prove themselves to be reliable, trustworthy partners, enabling multilateralization of disarmament efforts, and can testify to the nuclear-weapon states' credibility before the wider world.

Third, cooperation of states with civil society actors can create an additional dynamic. The role of civil society actors for European disarmament efforts has not been fully explored by this article. However, the example of the UK-Norway initiative indicates that fresh approaches and a mixture of relevant expertise can be achieved if states are willing to cooperate with civil society actors. Mixed coalitions might be more suited to develop new mechanisms (e.g. for verification involving civil societies) and gain broader support by the European public.

Fourth, Europe's advantages lie in the technical knowledge of many countries in civil nuclear energy, the NWS' special knowledge on military aspects, combined with the experience of longstanding cooperation and trust. Furthermore, Europe's reputation as a neutral negotiator is a strength when dealing with unsolved conflicts hindering disarmament and arms control.

Fifth, essential for European progress on disarmament will be to take advantage of any opportunity to alter the French position and to soften the country's inflexibility. France's willingness to cooperate closer with the UK, though mainly agreed to for financial reasons, hopefully creates an opportunity to develop common positions on more stable forms of deterrence, with further reduced numbers of warheads and an abandonment of the French airborne component. Ideally, a rapprochement of the countries' policies would mean that the UK, France and the US could better coordinate approaches to NPT nuclear-weapon states within the P5 consultations - and, in the future, to non-NPT nuclear-armed states. 